\title{
1983年国際製紙物性会議参加報告
}

㫼日本紙パルプ砸究所 岡川 章夫

\section{International Paper Physies Conference}

\author{
Akio Okagawa \\ Japan Pulp and Paper Research Institute
}

\section{1. はじめに}

紙の物性に関する著名な国際会議は, 英国の Oxford と Cambridge で交互に 4 年に 1 回開催されるFundamental Research Symposium である。その中間の年 に開催されている International Paper Physics Conference は昨年 9 月18日から22日までの 4 日間，米国 Massachusetts 州の Harwichport で閏催された。会場 となったWychmere Harbor Club \& Hotel は夏の保 養地として有名な Cape Codの一画にあるアメリカの 典型的なリゾートホテルである。ホテルは大西洋の海 に面した砂浜に建てられており，海水浴には肜分の
ない場所であるが，会議が行われた 9 月末ではシーズ ンも終り，海に入るには少々寒い位であった。会議の 参加者は全部で約 140 名, そのうち几本, カナダ, ス ウェーデン，フィンランド，イギリス，フランスなど の外国からの参加者は 40 名以上に達した。

会議は第 1 日から第 4 日末で，それぞれ特定のテー

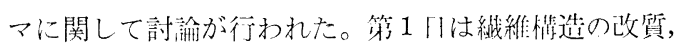

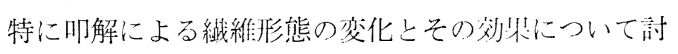
諭し，第2 日は紙の力学们強度，第317は䄉維閌結命， 最終日は紙の経時変化抢よび用途からみた紙の特性に ついて討樍が行わ机た。プログラムの内容は次の通り である。

\section{September 19, 1983}

\section{Session 1. Fiber Structure Modification}

Jouko Laamanen : "Measurement of Morphological Fiber Properties in Mechanical Pulps and their Relation to some Critical Paper Properties",

E. C. Da-Silva : "The Flexibility of Pulp Fibers-A Structural Approach"

S. Hietanen, K. Ebeling : "Homogeniety in Refining Action; Effects on Fiber and Paper Structure"

B. Higgins, R. Hartman : "Mechanical Treatment of Pulp Fibers for Sheet Property Development"

J. Thorpe, D. McLean : "Simulation of the Effects of Compression and Shear on Single Fibers"

\section{Session 2. Fiber Structure Modification (continued)}

W. Platt, R. Atalla : "Effects of Refining on Molecular Structure-An NMR Study of Cellulose and Water"

D. Page, J. Abbot: "Changes in Cellulose Structure During Pulping”

R. Atalla, R. Whitmore, C. Woitkovich : "Effects of Refining on Molecular Mobility in Cellulose" Panel on Refining : K. Ebeling, A. Nissan, D. Wahren

Moderator : E. Back

September 20, 1983

\section{Session 3. In-Plane Properties of Paper}

R. Seth, D. Page, M. Barbe, B. Jordan : "The Mechanism of the Strength and Extensibility of Wet Webs",

R. Perkins, R. Mark, J. Silvy, H. Anderson, A. Eusufzai : “Effect of Fiber (Orientation Distribution on the Mechanical Properties of Paper" 
M. Htun: "The In-Plane Mechanical Properties During Drying of Handsheets Made From Bleached Kraft and Thermo-Mechanical Pulps"

J. Skowronski, A. Robertson: "A Phenomenological Study of the Tensile Deformation of Paper"

R. Perkins, R. Mark, A. Eusufzai, C. Crosby : "A Study of the Inelastic Behavior of Paper"

\section{Session 4. Out-of-Plane Properties of Paper}

J. Waterhouse : (Out-of-Plane Shear Deformation Behavior of Paper and Board"

R. Mark, R. D. Cardwell, I. M. Allerby, R. Perkins, T. Uesaka : "The Relationship of Edgewise Compressive Strength to Inter-Laminar Shear Properties of Commercial Paperboards"

G. Baum, D. Shepard, K. Pers, T. Ave'Lallemant: "Wet Straining of Paper"

A. Michell, R. Seth, D. Page : "The Effect of Press Drying on Paper Structure"

D. Gunderson, R. Rowland : "Determining Paperboard Strength--Biaxial Tension, Compression, and Shear"

\section{September 21, 1983}

\section{Session 5. Bonding and Optical Properties of Paper}

D. Gunderson: "Temperature and Restraint Variables in Continuous and Intermittent Press Drying" I. B. Sachs : "The Bonding Mechanism of Pulp Fibers in Papermaking"

A. M. Scallan: "A New Approach to Kubelka-Munk Theory"

D. Wahren, J. Knox: "Determination of Light Scattering Coefficient of Dark and Heavy Sheets"

M. L. Miller, D.C. Paliwal: "The Effects of Lumen-Loading on Strength and Optical Properties of Paper"

\section{Session 6. Rheology of Paper \& Cellulose}

C. Green : "Relationship of Dimensional Stability to Rheology of Paper Structures"

B. Pankonin : "Viscoelastic Properties of Cellulosic Materials Using an Ultrasonic Rod Resonance Technique"

Panel on Bonding : D. Page, C. Fellers, R. Mark

Moderator : V. Byrd

September 22, 1983

\section{Session 7. Transient Properties of Paper}

E. Back, L. Salmen, G. Richardson : "Transient Effects of Moisture Sorption on Mechanical Properties of Lignocellulosic Materials"

V. Byrd: "Edgewise Compression Creep of Linerboard and Corrugating Medium in Cyclic Relative Humidity Environments"

L. Salmen, M. Rigdahl : "Predictions of Hygroexpansivity and Extensional Stiffness of Different Paper Structures by Mosaic Theory"

T. Kadoya :"Fatigue Phenomena of Single Pulp Fibers Under Repeated Torsional Stress"

R.H. Crotogino: "Effect of Conditioning on the Properties of Laboratory Calendered Newsprint"

\section{Session 8. Properties Relating to End Use}

M. B. Lyne, A. Whiteman, D.C. Donderi : "Multidimensional Scaling of Tissue Quality"

J. Oliver: "Paper Structure Development for Nonimpact Reprographic Printing Technologies"

J.S. Aspler, M. B.Lyne : "Surfactant Modification of the Dynamic Wettability of Paper"

J. Burnside, R.H. Crotogino: "Some Thermal Properties of Newsprint and Their Variations with Bulk"

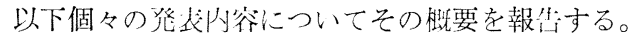


Table 1 Geometrical and physical properties of pulp fibers.

\begin{tabular}{|c|c|c|c|c|c|c|c|c|c|}
\hline & $\begin{array}{c}\text { Cell wall } \\
\text { cross- } \\
\text { sectional } \\
\text { area } \\
\left(\mu \mathrm{m}^{2}\right)\end{array}$ & $\begin{array}{l}\text { Fiber } \\
\text { peri- } \\
\text { meter } \\
(\mu \mathrm{m})\end{array}$ & $\begin{array}{c}\text { Fiber } \\
\text { diameter } \\
(\mu \mathrm{m})\end{array}$ & $\begin{array}{l}\text { Fiber wall } \\
\text { thickness } \\
(\mu \mathrm{m})\end{array}$ & $\begin{array}{l}\text { Luce's } \\
\text { shape } \\
\text { factor }\end{array}$ & $\begin{array}{c}\text { Cell } \\
\text { wall } \\
\text { density } \\
\left(\mathrm{g} / \mathrm{cm}^{3}\right)\end{array}$ & $\begin{array}{c}\text { Moment } \\
\text { of } \\
\text { inertia } \\
(\mu \mathrm{m})^{4}\end{array}$ & $\begin{array}{c}\text { Axial } \\
\text { young's } \\
\text { modulus } \\
(\mathrm{GPa})\end{array}$ & $\begin{array}{c}\text { Fiber } \\
\text { bending } \\
\text { stiffness } \\
\left(\mathrm{Nm}^{2} \times 10^{-12}\right)\end{array}$ \\
\hline Southern pin & 355.3 & 103.4 & 5 & 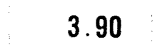 & 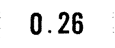 & 0.822 & 1,736 & 20.7 & 36.3 \\
\hline Silver birch & 136.7 & 56.2 & 17.9 & 2.90 & 0.37 & 0.732 & 363 & 9.0 & 3.3 \\
\hline E. grandis & 79.9 & 39.9 & 12.7 & 2.45 & 0.45 & 0.887 & 147 & 36.3 & 5.4 \\
\hline E. rostrata & 66.7 & 38.3 & 12.2 & 2.10 & 0.40 & 0.930 & 92 & 47.2 & 4.4 \\
\hline
\end{tabular}

\section{2. 繊維形態の影響}

紙の物㤛，特にその才学的特性に与える織維形態の 影響は大きい。繊維の形態は樹種により異なることは もちろんであるが，同一樹種でもパルプ化の方法や川 解の程度によっても形態の異なった䋐維ができる。紙 の種類は数多くあり, それぞれに特有の品質が要求さ れる。従って，入手可能な樹程からいかに有效に製品 品質に合った特性のパルプを作るかは，紙パルプ産業 にとって重要な淉題である。

抄紙に関わる䄉維の特性としては, 繊維の垃さ, 強 度，軸化，柔軟性㧍よび粗度なが重要な母子と唀えら れるが，その中でも絧維の柔軟性は紙層形成の際のな ビみやすさ (conformability) に関連するもので, 絓品 質にとっても最も重要視されている特性である。䋳維 の采軟性を测定する方法は，すぐにいくつか提然され ているが，いずれの方法も今まで知られている現象 を欲明するには不芫全である。そこでE. Claudio-

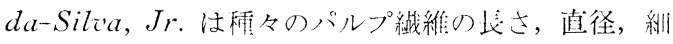
胞壁括さなどの测运から Leopold-Lyerの/法を仯い て䌦維の曲げ阙さを剑し，更にパルプのなじみやす さとしての指標を捉案した。䋊維の州げ剛さ $(S)$ は軴 方间のヤング率 $(E)$ と愪性モーメント $(I)$ の積で与え られる。

$$
S=E \times I
$$

帕貶されているサザンパイン，カバノキ，2 檑のユー カリの漂白パルプの織維形態の比較を表 1 に示す。カ バノキパルプの慣性モーメントはユーカリのそれと比 較してかなり大きい。また，ユーカリパルプのヤング 率はサザンパインより高い。しかし，曲げ楋さはサザ ンパインが最も䯩く，カバノキが最も低い。パルプ䄉 維の曲げ甽さだけからでは抄紙特性は判断できない。 Claudio-da-Silva はなじみやすさ $(C F)$ として， パ ルプ $1 \mathrm{~g}$ 当りの䄉維数 $(N)$ を取り入れた指標を提穼 した。

$$
C F=S \times N
$$

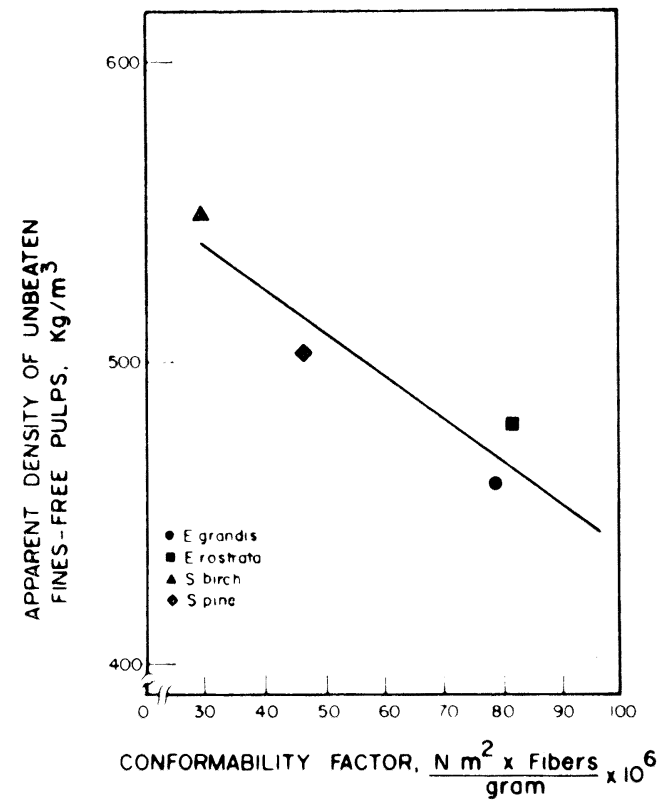

Fig. 1 Corrclation hetween the apparent density of unbeaten fines free pulps and the conformability factor.

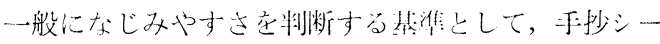
卜の密度が使わ机る。上沉 4 相のパルプり手抄シート 密度とCFを此較すると，図１に示すようにかなりよ い相関を示した。織維鬥状の测这のみからパルプとし

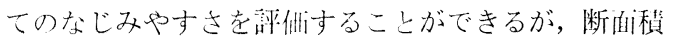
のかなり異なるユーカリ 2 暞の学を予测することはで きなかった。

KP の䋊維形態に比べて, 機悈パルプの䄉維形態は 製造乃法によ二ててかなり罢なり，抄紙特性，㧍よび紙

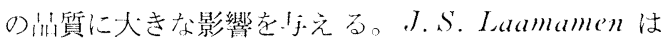
ノルウェースプルースのSGW(ストーン(GP), PGW

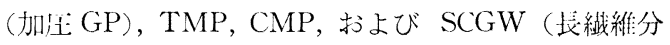
の少ないスーパーカレンダー朋の（iP) 上SBK（半徆

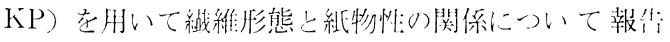
した。似用したパルプのフリーネス，䄉維上分分布を表 
Table 2 Pulp types and properties

\begin{tabular}{|c|c|c|c|c|c|}
\hline \multirow{2}{*}{ Pulp type } & \multirow{2}{*}{ Code } & \multirow{2}{*}{ Made by } & \multirow{2}{*}{$\begin{array}{l}\text { Freeness } \\
\quad(\mathrm{m} l)\end{array}$} & \multicolumn{2}{|c|}{ Bauer McNett fractions (\%) } \\
\hline & & & & +28 & +48 \\
\hline Fine groundwood & SCGW & Mill A & 33 & 0.7 & 16.6 \\
\hline Stone groundwood & SGW & Mill B & 72 & 12.5 & 21.5 \\
\hline Pressure groundwood & PGW & Mill B & 102 & 17.5 & 22.1 \\
\hline Thermomechanical pulp & TMP & Mill B & 100 & 28.0 & 24.7 \\
\hline Chemimechanical pulp & CMP & Pilot & 600 & 50 & 21 \\
\hline Semi-bleached kraft beaten to SR $20^{\circ}$ & SBK & Mill $\mathrm{C}$ & 650 & 57 & 23 \\
\hline
\end{tabular}

Table 3 Proportions of different types of fibrous particles in the pulp fractions

\begin{tabular}{c|c|c|c|c|c|c}
\hline \multirow{2}{*}{ Pulp } & \multirow{2}{*}{ Fraction } & \multicolumn{3}{|c|}{ Single fibers (\%) } & \multirow{2}{*}{$\begin{array}{c}\text { Shives } \\
(\%)\end{array}$} & $\begin{array}{c}\text { Split } \\
\text { fibers } \\
(\%)\end{array}$ \\
\cline { 2 - 5 } & & Straight & Curled & Total & 12 & 11 \\
\hline SCGW & +28 & 55 & 22 & 77 & 12 & 11 \\
S GW & $\prime$ & 55 & 18 & 73 & 16 & 6 \\
P GW & $\prime$ & 57 & 21 & 78 & 16 & 0 \\
TMP & $\prime$ & 85 & 14 & 99 & 1 & 0 \\
CMP & $\prime \prime$ & 82 & 18 & 100 & 0 & 0 \\
S B K & W. & 55 & 45 & 100 & 0 & 0 \\
SCGW & +48 & 56 & 17 & 73 & 13 & 14 \\
S GW & $\prime$ & 55 & 13 & 71 & 11 & 18 \\
P GW & $\prime$ & 52 & 21 & 73 & 12 & 15 \\
TMP & $\prime$ & 82 & 13 & 95 & 2 & 3 \\
\hline
\end{tabular}

Table 4 Structural modifications of single fibers.

\begin{tabular}{|c|c|c|c|c|c|c|}
\hline \multirow{2}{*}{ Pulp } & \multirow{2}{*}{ Fraction } & \multicolumn{5}{|c|}{ Structural modifications per $\mathrm{mm}$ of fiber length } \\
\hline & & Fibrillation & Kink index & Twists & $\begin{array}{c}\text { Wall } \\
\text { fractures }\end{array}$ & $\begin{array}{c}\mathrm{ML} \text { and } \mathrm{RC} \\
\text { retention }\end{array}$ \\
\hline SCGW & +28 & 0.51 & 0.03 & 0.04 & 0.08 & 0.11 \\
\hline S GW & " & 0.28 & 0.11 & 0.05 & 0.02 & 0.03 \\
\hline P GW & " & 0.16 & 0.06 & 0.08 & 0.04 & 0.02 \\
\hline $\mathrm{TMP}$ & " & 0.03 & 0.18 & 0.30 & 0.01 & 0.00 \\
\hline $\mathrm{CMP}$ & " & 0.13 & 0.08 & 0.09 & 0.03 & 0.01 \\
\hline $\mathrm{S} \mathrm{BK}$ & W. & 0.04 & 0.82 & 0.20 & 0.01 & 0.00 \\
\hline SCGW & +48 & 0.91 & 0.02 & 0.04 & 0.09 & 0.26 \\
\hline S GW & " & 0.27 & 0.06 & 0.12 & 0.04 & 0.10 \\
\hline P GW & " & 0.39 & 0.04 & 0.06 & 0.09 & 0.09 \\
\hline TMP & " & 0.08 & 0.09 & 0.28 & 0.03 & 0.01 \\
\hline
\end{tabular}

2 に示す。これらのパルプの長織維分, 特に BauerMcNett の +28 と +48 フラクションの単織維の形態的 特徵を表 3 と 4 に示す。GP には直すぐな㵶維は $55 \%$ 程度であるが，TMP，CMP には $80 \%$ 以上含まれて いる。SBK ではカールした繊維が非常に多い。瀻維 昭和 59 年 $(1984) 3$ 月
のフィブリル化は SCGW が最も多く，他のパルプと は極端な差がある。SBK はカールも多いが, 同時に キンクも多い。その他のパルプには，キンクはわずか しかない。一方，TMP はねじれが非常に多い。 SCGW を基準にして, SCGW を $80 \%$ に対して, 


同川章少

Table 5 Paper properties of laboratory handsheets made either of pure SCGW pulp or of mixtures of pulp fractions (20\%) and SCGW pulp (80\%).

\begin{tabular}{|c|c|c|c|c|c|c|c|c|}
\hline \multirow{2}{*}{$\begin{array}{l}\text { Added } 20 \% \\
\text { of pulp } \\
\text { fraction }\end{array}$} & \multirow{2}{*}{$\begin{array}{c}\text { Base } \\
\text { SCGW } \\
\text { pulp (\%) }\end{array}$} & \multicolumn{3}{|c|}{ Wet web properties } & \multirow{2}{*}{\begin{tabular}{|c|}
$\begin{array}{c}\text { Apparent } \\
\text { density } \\
\left(\mathrm{kg} / \mathrm{m}^{3}\right)\end{array}$ \\
\end{tabular}} & \multirow{2}{*}{$\begin{array}{l}\text { Tensile } \\
\text { index } \\
(\mathrm{Nm} / \mathrm{g})\end{array}$} & \multirow{2}{*}{$\begin{array}{c}\text { Stretch } \\
(\%)\end{array}$} & \multirow{2}{*}{$\begin{array}{l}\text { Tear index } \\
\left(\mathrm{mN} \cdot \mathrm{m}^{2} / \mathrm{g}\right)\end{array}$} \\
\hline & & $\begin{array}{c}\text { Tensile index } \\
(\mathrm{Nm} / \mathrm{g})\end{array}$ & $\begin{array}{c}\text { Stretch } \\
(\%)\end{array}$ & $\begin{array}{c}\text { TEA index } \\
(\mathrm{mJ} / \mathrm{g})\end{array}$ & & & & \\
\hline - & 100 & 0.70 & 10.2 & 57 & 422 & 29.7 & 2.1 & 2.45 \\
\hline $\mathrm{S} \mathrm{GW}+28$ & 80 & 0.74 & 8.6 & 51 & 361 & 27.3 & 2.3 & 3.43 \\
\hline $\mathrm{P} \mathrm{GW}+28$ & 80 & 0.84 & 7.8 & 55 & 371 & 28.6 & 2.2 & 3.87 \\
\hline $\mathrm{TMP}+28$ & 80 & 0.86 & 8.3 & 61 & 383 & 29.9 & 2.0 & 4.51 \\
\hline $\mathrm{CMP}+28$ & 80 & 0.50 & 9.4 & 66 & 410 & 32.3 & 2.3 & 4.25 \\
\hline S B K W. & 80 & 0.97 & 10.4 & 79 & 439 & 35.6 & 2.7 & 4.90 \\
\hline $\mathrm{S} \mathrm{GW}+48$ & 80 & 0.71 & 8.6 & 51 & 376 & 28.1 & 2.5 & 2.67 \\
\hline $\mathrm{PGW}+48$ & 80 & 0.74 & 9.0 & 55 & 377 & 28.9 & 2.4 & 2.74 \\
\hline $\mathrm{TMP}+48$ & 80 & 0.80 & 8.8 & 60 & 390 & 29.0 & 2.2 & 2.92 \\
\hline
\end{tabular}

Table 6 Paper properties of laboratory handsheets made either of pure SCGW pulp or of mixtures of pulp fraction (20\%) and SCGW pulp (80\%).

\begin{tabular}{c|c|c|c|c|c}
\hline $\begin{array}{c}\text { Added 20\% } \\
\text { of pulp } \\
\text { fraction }\end{array}$ & $\begin{array}{c}\text { Base SCGW } \\
\text { pulp (\%) }\end{array}$ & $\begin{array}{c}\text { Light scattering } \\
\text { coefficient } \\
\left(\mathrm{m}^{2} / \mathrm{kg}\right)\end{array}$ & $\begin{array}{c}\text { Bonding strength, } \\
\text { Scott bond } \\
\left(\mathrm{J} / \mathrm{m}^{2}\right)\end{array}$ & $\begin{array}{c}\text { Roughness, } \\
\text { Bendtsen, 98 } \mathrm{kPa} \\
(\mathrm{m} / / \mathrm{min})\end{array}$ & $\begin{array}{c}\text { Bending stiffness, } \\
\text { Kodlak } \\
(\mathrm{mN} \cdot \mathrm{m})\end{array}$ \\
\hline- & 100 & 77.7 & 368 & 1,390 & 0.108 \\
S GW +28 & 80 & 68.5 & 193 & 2,100 & 0.164 \\
P GW +28 & 80 & 67.3 & 200 & 1,900 & 0.140 \\
TMP +28 & 80 & 69.5 & 212 & 1,700 & 0.134 \\
CMP +28 & 80 & 63.3 & 309 & 1,570 & 0.149 \\
S BK W & 80 & 66.1 & 427 & 1,500 & 0.152 \\
S GW +48 & 80 & 72.9 & 231 & 1,620 & 0.148 \\
P GW +48 & 80 & 72.1 & 223 & 1,600 & 0.161 \\
TMP +48 & 80 & 71.1 & 211 & 1,550 & 0.150 \\
\hline
\end{tabular}

それぞれ各種のパルプの长䋐維分を $20 \%$ 加えたパル プの手抄シート特性を表 5 および 6 に示す。湿紙引張 強さはパルプの織維長が長くなるに伴って増大し, $\mathrm{SBK}>\mathrm{TMP}>\mathrm{PGW}>\mathrm{CMP}$ の順であるが, 紙の引張 強さにはそれほど大きな影響を与えない。伸びの増加 は外部フィブリル化と䊼維末端のほぐれに関係してい ると思われる。長瀻維分の影響が顕著に現われるのは 引裂強さで, SBK を20\% 加えると 2 倍近くの強さが 得られる。引裂強さの順仙は $\mathrm{SBK}>\mathrm{TMP}>\mathrm{CMP}$ で あるが，この傾向は平均䋊維長の順位とは全く反対で ある。光散乱係数, スコット結合強度はともに長繊維 分が混じると低下する。例外は SBK を加えた場合の スコット結合強度で SCGW より高い。機械パルプに は結束繊維が多いので, 当然の結果として表面粗さが 増大する。

以上の結呆から紙品質に与える瀻維形態の重要な因 子として, 繊維長, 外部フィブリル化, 単瀻維と結束
繊維の比率，およびキンク指標であると萖うことがで きると Laamamen は結諭している。

紙品質に適した䋊維に改質する一つの才法として吒 解がある。通常の低濃度叮解ではパルプがフロック状 となり，全繊維が均一に叮解されていないと思われる。 この欠点を改めるためにヘルシンキ工科大学の $K$. Ebeling らはフロック在分散させて均一に叨解させる 装置を工夫した。しかし，均一な吒解が紙品質に良い 影響を与えるのかどらかは不明だし，またそれによっ て效率の高い（すなわちエネルギー消費の少ない）吒 解が達成されるかどらかはわからない。リファイナ

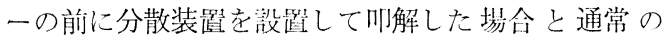
Esher-Wyss リファイナーによって叮解されたパル プの膨潤度を比較すると図 2 のようになる。EsherWyss リファイナーで川解したパルプでは $60 \%$ 近い繊 維はほとんど吒解されていない。这にこの奏験で使っ た分散装置をつけたリフォイナーでは緟潤度の高い織 
Table 7 Results from characterization of the new refining principle

\begin{tabular}{|c|c|c|c|c|c|c|}
\hline \multirow{3}{*}{ Property } & \multicolumn{5}{|c|}{ Type of furnish and its drainage resistance } & \multirow{3}{*}{$\begin{array}{c}\text { Statistical } \\
\text { significance } \\
\text { of * } \\
\text { differences }\end{array}$} \\
\hline & \multirow{2}{*}{$\begin{array}{c}\text { Unbeaten } \\
14^{\circ} \mathrm{SR}\end{array}$} & \multicolumn{2}{|c|}{ Experimental refiner } & \multicolumn{2}{|c|}{ Escher-Wyss refiner } & \\
\hline & & $15^{\circ} \mathrm{SR}$ & $20^{\circ} \mathrm{SR}$ & $15^{\circ} \mathrm{SR}$ & $20^{\circ} \mathrm{SR}$ & \\
\hline Swelling degree of fibers in $\mathrm{CED},(\%)$ & 6.1 & 22.0 & 31.5 & 15.4 & 21.0 & ++ \\
\hline WRV water $(\%)$ & 141 & 168 & 210 & 173 & 199 & - \\
\hline WRV ether $(\%)$ & 61 & 57 & 64 & 62 & 50 & - \\
\hline$W R V_{\text {water }}-W R V_{\text {ether }}(\%)$ & 80 & 111 & 150 & 111 & 149 & - \\
\hline Mean fiber length (mm) & 2.1 & 2.0 & 1.7 & 2.0 & 1.8 & + \\
\hline Contact ratio $(\%)$ & 18.7 & 24.0 & 33.0 & 21.0 & 27.0 & ++ \\
\hline Relative bonded area $(\%)$ & 27.4 & 33.0 & 37.7 & 34.4 & 38.1 & - \\
\hline Light scattering coefficient $\left(\mathrm{m}^{2} / \mathrm{kg}\right)$ & 35 & 32.9 & 30.6 & 32.6 & 30.4 & - \\
\hline Opacity $(\%)$ & 75.1 & 74.1 & 72.9 & 74.0 & 73.0 & - \\
\hline Density $\left(\mathrm{kg} / \mathrm{m}^{3}\right)$ & 420 & 480 & 495 & 475 & 500 & - \\
\hline Tensile index $(\mathrm{Nm} / \mathrm{g})$ & 25.9 & 38 & 50 & 41 & 53 & - \\
\hline $\operatorname{Tear}_{i} \operatorname{index}_{i}^{-}\left(\mathrm{mNm}^{2} / \mathrm{g}\right)$ & 16.35 & 18.95 & 13.25 & 17.60 & 14.35 & - \\
\hline Zero-span tensile (FSI) $(\mathrm{Nm} / \mathrm{g})$ & 148 & 136 & 139 & 142 & 141 & - \\
\hline Rupture elongation $(\%)$ & 3.5 & 4.3 & 5.1 & 4.5 & 4.7 & + \\
\hline Shrinkage during free drying $(96)$ & 2.7 & 3.6 & 4.4 & 3.4 & 3.9 & - \\
\hline Drying stress $(\mathrm{Nm} / \mathrm{g}) * 1$ & 1.6 & 2.1 & 3.2 & 1.9 & 2.1 & $(++)$ \\
\hline $\begin{array}{l}\text { Relative rate of stress relaxation at } 90 \% \\
\text { tensile load }\end{array}$ & 0.09 & 0.69 & 0.10 & 0.09 & 0.08 & - \\
\hline Elastic modulus $(\mathrm{Nm} / \mathrm{g} / \%)^{* 2}$ & 23.0 & 29.0 & 35.3 & 26.0 & 36.2 & - \\
\hline $\begin{array}{l}\text { Relative rate of creep during } \\
\text { apparent plastic straining of paper*3 }\end{array}$ & 0.87 & 0.83 & 0.85 & 0.78 & 0.82 & + \\
\hline Gurley-Hill porosity (sec) & 1.0 & 1.8 & 8.5 & 2.4 & 7.8 & + \\
\hline \multirow{2}{*}{$\begin{aligned} \text { Bendtsen-roughness }(\mathrm{m} / / \mathrm{min}) & \text { top side } \\
& \text { wire side }\end{aligned}$} & 1,640 & 1,540 & 1,430 & 1,410 & 1,370 & + \\
\hline & 1,640 & $1, \mathrm{EgO}$ & 1,470 & 1,440 & 1,410 & + \\
\hline
\end{tabular}

$* 1$ Relative values, *2 Elongation expressed in percentage, $* 3$ See reference (20), * ++ very significant, + slightly significant, - no difference

維が增大している。しかし，これでも筦全に均一な吒 解が行われたとは言いがたい。この 2 者の叨解によっ て調整された手抄シート特性を表 7 に示す。均一吒解 によって得られたパルプはキンクが多く, 絸胞壁の收 繀が大きいため，一見麗濃度叮解したパルプと同様な 傾向を示している。门倨強さと引裂強さの関係を図 3 に示す。均一川解パルプは叮解初期段階では引裂強さ が急激に増大するが，川解が進むにつれて娍少し， Esher-Wyss リファイナーよりも䍐以結果となる。エ ネルギー消費面から，引裂強さの最大值を得る点で比 較すると，約 $40 \%$ の省エネルギーを達成することが 昭和 59 年 (1984) 3 月
できる。

吒解によって繊維形態が変化し，それが紙品質に大 きな影響を与えることは周知の事奏であるが，そのメ カニズムについては完全に解明されているとは言えな い。吅解により緎維の内部フィブリル化と外部フィブ リル化が起るが，これらを別々に起す装置を工夫し， それぞれの效果について IPCの R. R. Hartman と B. G. Higgins が检討した。内部フィブリル化を起 すために繊維に繰返し圧綰を与えるロールリファイナ 一を使い，外部フィブリル化は瀻維同志を摩摖させる 䧹研型リファイナーを使って実験した。両者の概略図 


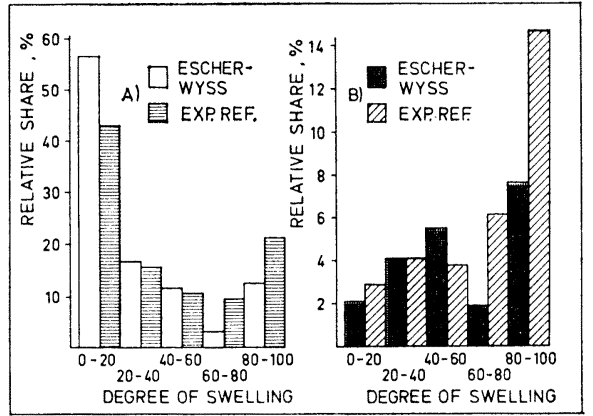

Fig. 2 Effect of moderate refining ( $20^{\circ} \mathrm{SR}$ ) on the variation of the degree of swelling expressed (A) on the basis of number of fibers and (B) on the total length basis.

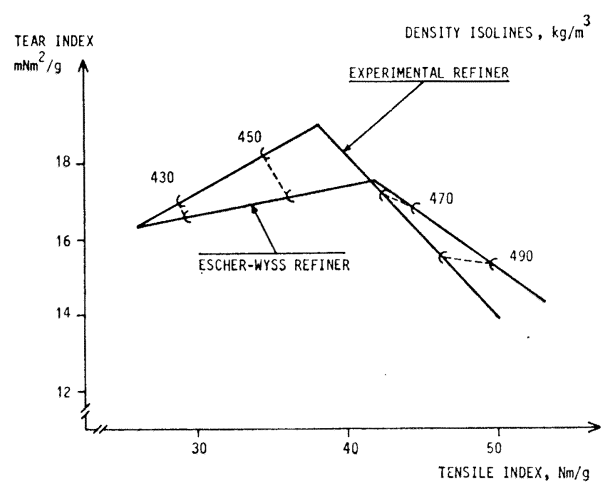

Fig. 3 Relationship between tear strength and tensile strength during refining.

を図4 と 5 に亦す。ロールリファイナーは叫解すべき パルプを Formette Dynamique シートマシンで作っ た固形分 28〜30\% の湿紙シートをロールDに然きつ け，その上から溝をきざんだロールCに何重をかけて， ロールDを回転させて吅解するものである。䕌砕型リ ファイナーでは固定板と回転板の間にパルプをはさみ， 回転力により外部フィブリル化を起す装置である。こ の 2 つの装琵を使って，スプルースの BSP に対する 吒解の效果について検討した。

ロールリファイナーで吅解したパルプの䄉維長分布 は吒解前のパルプとほとんど変りがないが，シート泌 度は朋らかに増大する。電了顕微鏡で観察するとロー ルリファイナーで吒解したパルプは䊼胞壁のデラミネ ーションが大きく，外部はほとんどそのままの形状を 保っている。従って，フリーネスの低下は全くない。 引裂強さと裂断長の関係は典型的な極大值を示し, 通 常の叮解と変りはない。ただし, 裂断長は最高 $5.8 \mathrm{~km}$ で, 通常叮解パルプよりも低い。裂断長とシート密度

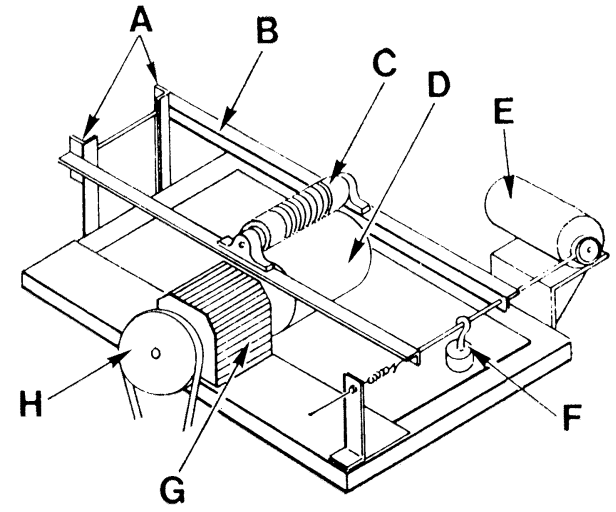

Fig. 4 Schematic of the roll refiner.

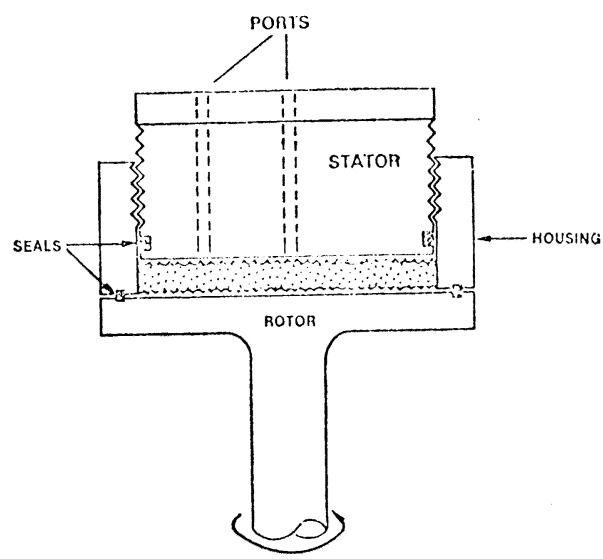

Fig. 5 Schematic of the abrasion refiner.

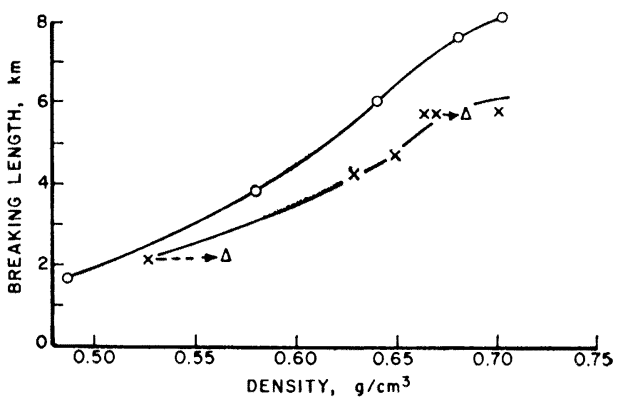

$X:$ roll refined pulp

$O:$ Valley beaten pulp

$\triangle:$ abrasion treatment

Fig. 6 Breaking length vs. density.

の関係を図 6 に，末た，比敬淤係数との関係を図 7 に 示す。ロール仃解されたパルプは，シート密度が高い わりには裂断長が低い。これに対し同一裂断長で比較 すると比散乱係数が小さくなる。すなわち，相対結合 面積が増大していることを坣味している。ロール叨解 


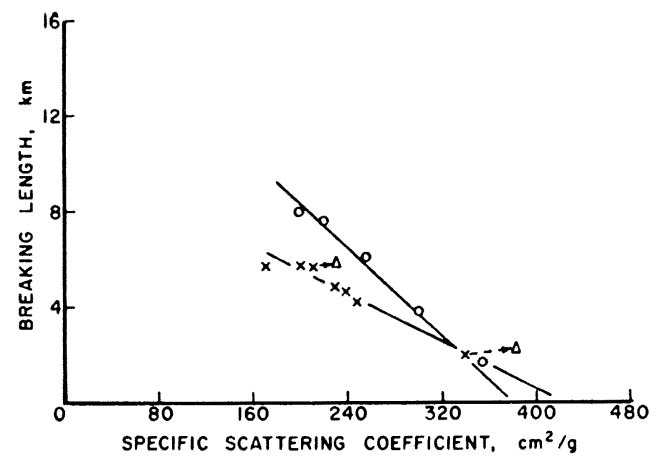

$x:$ roll refined pulp

0 : Valley beaten pulp

$\Delta:$ abrasion treatment

Fig. 7 Breaking length vs. specific light scattering coefficient.

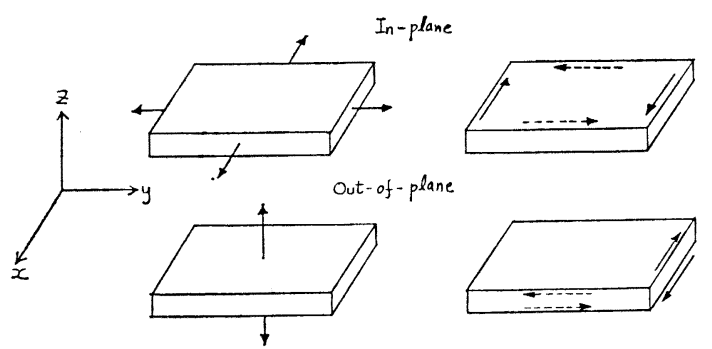

Fig. 8 Schematics of In-plane and Out-ofplane Deformations.

されたパルプは結合面積を増大させるにもかかわらず， 裂断長の増加は小さい。

これに対してロール叮解されたパルプを麻砕型リフ アイナーで外部フィブリル化を促進させてもシート密 度, 比散乱係数は増大するが, 裂断長はほとんど変ら ない。しかし，ロール吒解したパルプに 16\% のファ インを添加すると裂断長, 密度ともに増加し, 通常叨 解パルプの特性に近付くことが実証された。ただし，

比散乱係数はほとんど変らない。

この実験結果から言えることは队部フィブリル化に より裂断長の増大を期待することはできないし，また それを外部フィブリル化したとしても裂断長の増加も ない。しかし，微絒䄉維が存在すると裂断長は急激に 増加することから，微縕䄉維が䋐維間結合に重要な役 割を果していると言える。

吒解はパルプ形態に様々な変化をおよぼす。内部フ ィブリル化, 外部フィブリル化, キンク, 枚じれ, 切 断, 微細繊維の生成などが起る。形態変化に対する砄 昭和 59 年 (1984) 3 月
究に対して, 叨解によりセルロースや他の構成要素に 何が起っているのか, といら分子レベルでの碑究は少 ない。R.H. Attala らは, NMR とラマン分光を使っ て分子レベルでの叨解の影響について検討した。セル ロースと会合している水分子の易動性を NMR で测定 することにより，七ルロースの構造変化を柃出するこ とができる。例えば，スプルースの酔バイサルファイ トパルプをPFI ミル 3,000 回軾叮解したパルプでは, セルロースと会合している水の量が $22 \%$ 増大する。 一方ラマン分光では, セルロースI，七ルロースI少 よび非結晶セルロースの量を㛟出寸をことが可能であ る。低から中程度の吒解ではセルロース I, II, 非絬 晶部の割合はほとんど変らないが, 高叮解 $(24,000$ 回 転）したパルプではセルロースIが大幅に增加する。 このことから叨解の初期ではデラミネーションが徐々 に進行し, その後ラメラ队部の破壊が起ることがわか る。また, 高叮解されたパルプは, 低濃度のカセイン 一ダ浴液で容易にマーセル化されることからもラメラ 内部に構造変化が起きていることが訨明できる。

\section{3. 紙の力学的特性}

紙を一つの物体として洘えた時に，その物体に加わ る力（応力）とそれによって生ずるひずみは，平衡状 態にある場合は，それぞれ 6 成分で表わすことができ る。直方体の面に垂值に働く力が 3 成分, 対称となる 面の接線方向に働く力が 3 成分ある。これを紙に適用

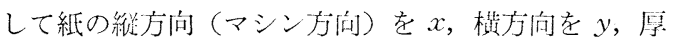
さ方问を $z$ とする， $x, y, z$ 方向の弱張りあるいは 生維の変形と, それぞれの軸に垂直な面のずり変形と がある。紙のように極端に薄い物体に対しては，面队 と面外の特性に分けて, 济える方が便利である。これ を模式的に表わしたのが図 8である。间内特性とは, $x, y$ 方向の引跤り・圧緥および面けのずり変形を言 い，面外特性とは $z$ 方向の引㖘り・压綃および紙の上 下面でのずり変形を言う。弾性領域の変形については, それぞれに対応して弾业率が応力とひずみを関係ずけ る係数となる。従って, 面内特性では $x, y$ 方向の弾 性率 $E_{x}, E_{y}$ およびずり弾性率 $G_{x y}$ であり, 面外特 性は $E_{z}, G_{x y}, G_{y z}$ である。紙の力学特性では, 特に 面内特性についての研究は古くから行われており, 数 多くの知見が得られているが，面外特性についてはよ らやく最近になって注目されるようになった。

紙の力学的特性は紙品質に関わる問題のみでなく, マシンの操業性に関しても重要な特性である。マシン の操業性を判断する指標としてPPRICのD.Page ら は図 9 に示すような“破壊包絡線”の椹念を導入した。 


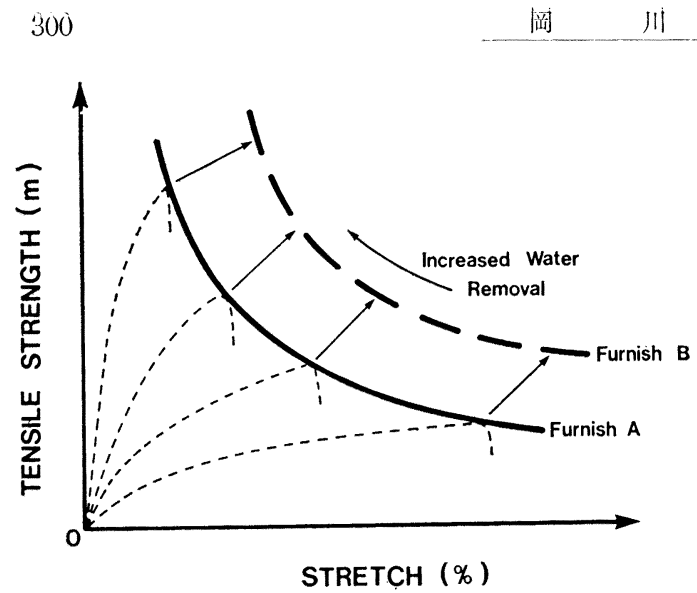

Fig. 9 Failure envelopes for two furnishes. Arrows in this failure envelopes connect points obtained at similar dewatering conditions. Since furnish B has a higher failure envelope, it is expected to run better.

水分䁷の異なる湿紙の S-S 曲線の極大点を結んだもの が破壊包絡線である。湿紙の受けるひずみがこの氾絡 線より下であれば断紙が起ることは少ないであろう。 マシンでの断紙を少しでも防ぐためにはこの包絡線が より右上にあることが望ましい。当然のことながら叨 解したパルプの破猿包絡線は右上に移動する（図 10）。 また,ファインを除去したパルプでは, 破壊包絡線は 逆に左下に移動する。破壊包絡線を右上に移動させる ためのパルプの処理方法の一つとしてパルプ繊維にカ ールやマイクロコンプレッション（䋊維細胞壁内部の ミク口な内部破壤）を導入することが考えられる。パ ルプを家庭用ミキサーで撹拌してカールを与えたパル プは湿紙引险強さはわずかに減少するが，伸びが増大 するため, 結果として破壊包絡線は右に移動する（図 11)。従って, TMP のようなパルプのレイテンシーを 除くことはカールを除くことになり，破壊包絡線は左 下に移動するので, 結果としてマシン操業性が㦞くな ると言える。湿紙固形分が低い所では繊維のカールが 伸びを増大させるが，固形分が増大するに伴い伸びを 増大させる要因としては維維細胞壁のマイクロコンプ レッションが重要な役割をはたす。

紙の力学的特性, 特にその面内特性は維維の配问分 布と密接な関係にある。維維の配问分布の测定は最近 の画像解析装置の発详により容易にできるようになっ てきている。しかしながら，まっすぐでない維維のど こを基準にして配向を決めるかが大きな間題となる。 一本の維維としての配问ではなく, 維維をいくつかの 七グメントに分けて, その配向を测定することも考え
章 犬

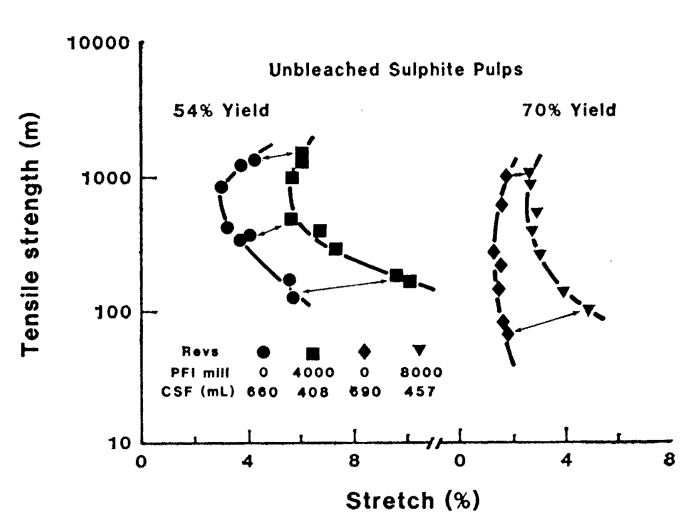

Fig. 10 The effect of beating on failure envelopes for laboratory-made, neverdried sulphite pulps. The 70\%-yield pulp was first defibred in a singledisc laboratory refiner and screened. The beating was carried out at $10 \%$ consistency in a PFI mill.

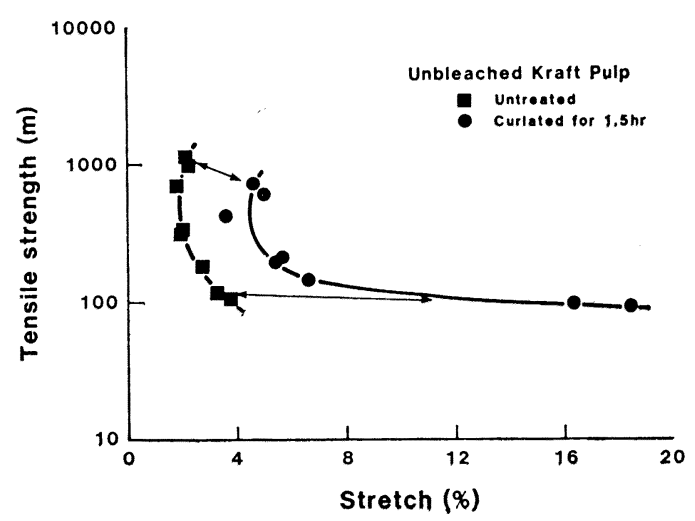

Fig. 11 The effect of curlation on the failure envelope for a never dried, 46\%yield, laboratory-made, unbleached kraft pulp of softwood. The fibres of the original pulp were straight. They were curlated by treating the pulp at $20 \%$ consistency in a Hobart kitchen mixer.

られる。米国の ESPRI，スウェーデンのSTFI，フラ ンスの $\mathrm{EFP}$ で同一サンプルで配问分有を测定した結 果では，それぞれ異なる力法で测是したにもかかわら ず全体としては比較的よい一致を坴した。維維配问分 布老

$$
f(\theta)=\frac{1}{\pi}\left[1+a_{1} \cos 2 \theta+a_{2} \cos 4 \theta\right]
$$

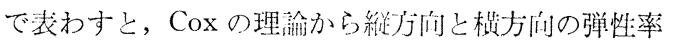
の比は次の関係で与えられる。 
Table 8 Comparison of ratio of $\mathrm{MD}$ to $\mathrm{CD}$ Young's moduli determined by calculation from fiber orientation measurement and direct mechanical test.

\begin{tabular}{c|c|c|c}
\hline $\begin{array}{c}\text { Basis } \\
\text { weight }\end{array}$ & $\begin{array}{c}\text { Orientation } \\
\text { level } \\
\text { designation }\end{array}$ & Calculated ${ }^{* 1}$ & $\begin{array}{c}\text { Mechanical } \\
\text { measurement }\end{array}$ \\
\hline 30 & 1 & 1.40 & 1.34 \\
30 & 2 & 1.92 & 1.75 \\
30 & 3 & 4.71 & 4.55 \\
30 & 4 & 3.63 & 3.83 \\
30 & 5 & 4.77 & 5.42 \\
\hline
\end{tabular}

*1 Based on ESPRI measurement according to BFCL, definition.

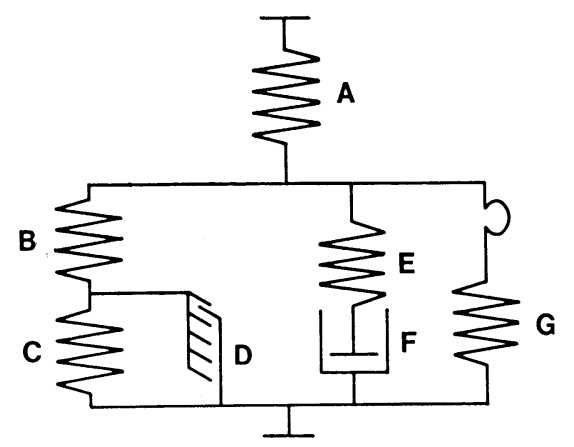

Fig. 12 A mechanical model proposed to simulate the observed response of paper to tensile loading. Elements $\mathrm{A} B \mathrm{C} \mathrm{E}$ and $\mathrm{G}$ are springs, $\mathrm{F}$ is a viscous dashpot, $\mathrm{D}$ is a ratchet. $\mathrm{G}$ represents elements that are activated or broken by extension.

$$
\frac{E_{M D}}{E_{C D}}=\frac{6+4 a_{1}+a_{2}}{6-4 a_{1}+a_{2}}
$$

ここで $a_{1}, a_{2}$ は䋊維配间の皮测值から沃められる定 数である。䋊維配问の実测值から求めた弾性率の此上, 実测した弾幽率の比を比較すると表 8 のよらな一致を 示した。ただし，配们度の高いレベル 5 の紙では战算

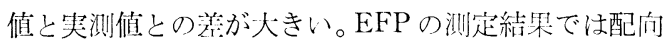
分布は䋊維長分有に無関係でなく, 何らかの関係があ ることを示唆している。従って, 䊼維配问分布から紙 の力学的特性をより正確に予测するためには, 繊維死 分布上配们分布を合一させた多重分有で表わす必要が ある。

一般に紙の力学似特性は将似条件のもとで測定され るが，動的条件のもとで测定された力学的特性も抄紙 特性を知る上で禹要である。 M. Htun は BKP およ
びTMPの手抄シートの振動粘弾性を测定した。その 結果，固形分 80 90\% の所で動的損失が極大となり, 固形分 40 50\% 付近で損失正切が極大を示した。極 大值は BKP の方が TMP よりもはるかに高い值を示 した。この極大值が現われることはこの付近でセルロ 一ス構造に転移が起きていることを意味している。 $\mathrm{B}$ $\mathrm{KP}$ と TMP の差は繊維の微細構造に基因するものと 思われるが，今後の研究が必要である。

振動式測定とは異なり静的条件下で, 特に非弾性領 域に達した後, 回復・再荷重を繰り返し与えることに より，紙層構造と力学特性を関係ずけることができる。 更に応力緩和やクリープ実験のデータから紙の力学的 モデルとしてA.A. Robertson らは図 12 に示したも デルを提案した。弾甠挙動をスプリング A, B, C, E で示し, 粗弾性は EF の Maxwell 要素で, 塑性変形 と内蔀応力は CD で表わすことができる。Dはノコギ リ料のよらなもので，一度引腿られるとそこにとどま り塑性変形を表わし，その時の応力はCで表わされる。 $\mathrm{G}$ Gスプリングはその上にあるループが伸びたときに 初めて作用するもので, 繰返し荷重により弾性領域が 広がることをモデル化したものである。これらの要素 と紙の構造, あるいは䋐維特性との対応は今後検討さ れるべき課題である。

SUNY の R.W. Perkins と R.E. Mark のグル 一プは先に述べた繊維配问分布の测定および紙断面で の䄉維間結合の测定から, 塑性変形領域の力学的特性: との関係を検討した。繊維を弾性部分と塑性部分にわ け，それぞれに対応する弾性率と配向分布から紙の塑 性変形領域の力学特性を予测する理論式を尊いたが, 丰際の現象を完全に説明するには至らなかった。

实際の紙の用途から考えると，一方向のみの力学特 性では紬品質を評価することはできない。2 軸方向の 同時引㖪り，圧縮，あるいはずり変形に対して紙がい かに応答するかを知らなければならない。このような 条件下で力学特性を測定する方法はいくつか提案され ている。D.E. Gurderson と R. E. Rowlands も新 しい方法を考案し，その実験結果について報告した。 この装置の概略を図 13 および 14 に示す。

以上，面内特性について述べてきたが，次に面外特 性について述べる。面外特性の一つは紙の上下面にそ って互に反対方向の力を働かせると暻さ方向にずり変 形が起きる。板紙や中しん原紙ではこの特性は重要で ある。これを测定する方法もすでにいくつか提案され ている。J.F. Waterhouse は図 15 に示すような回 転円板型の測定法を考案した。この場合のずり弾性率 $G$ は, 紙の厚さ $t$ に角変位 $\theta$ によって発生するトルク 


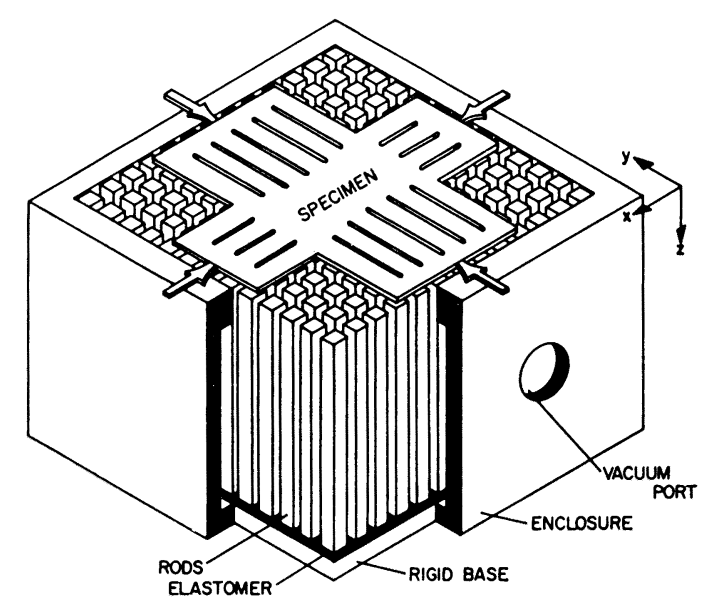

Fig. 13 Vacuum restraint concept in biaxial configuration. Rods are $3 \mathrm{~mm}$ by 3 $\mathrm{mm}$ by $115 \mathrm{~mm}$. Space between rods is $0.7 \mathrm{~mm}$.

(b)
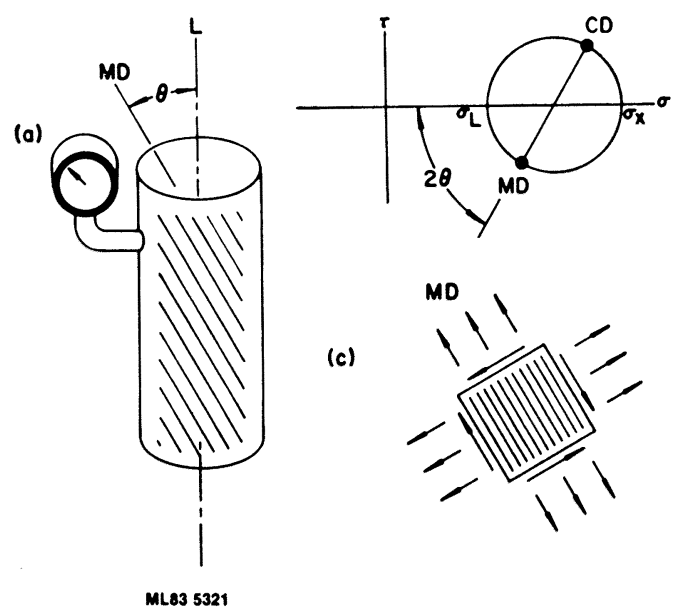

(c)

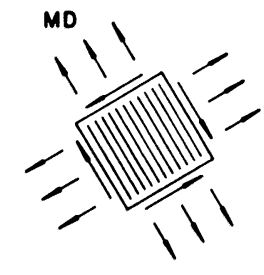

(a) Pressurized cylinder.

(b) Determining stresses in $\mathrm{MD}$ and $\mathrm{CD}$ using Mohr's circle.

(c) Resulting state of stress in $\mathrm{MD}$ and $\mathrm{CD}$ coordinates.

Fig. 14 Off-axis cylinder specimen.

$T$ と円板面の 2 次モーメント $J$ から $G=T t / \theta J$ で与 えられる。この $G$ は紙の綎方向と横方向に関連した 面外ずり弾性率の幾何平均で与えられるので $G=2$ $G_{x z} /\left(G_{x z}+G_{y z}\right)$ の関係にある。図 16 と 17 に超音波 で测定したずり弾幽率の結果を示した。超音波测定で は $G$ は坪量の増加にともなって増大する傾向にある。 これと反対に円板式测定では坪量の増加にともなって ずり弾兆率はむしろ娍少する傾向にある。

章 夫

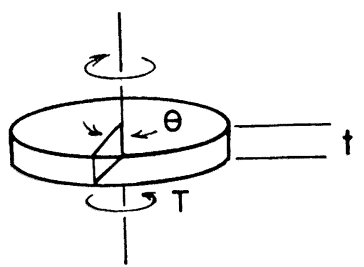

Fig. 15 Torsion of thin disk.

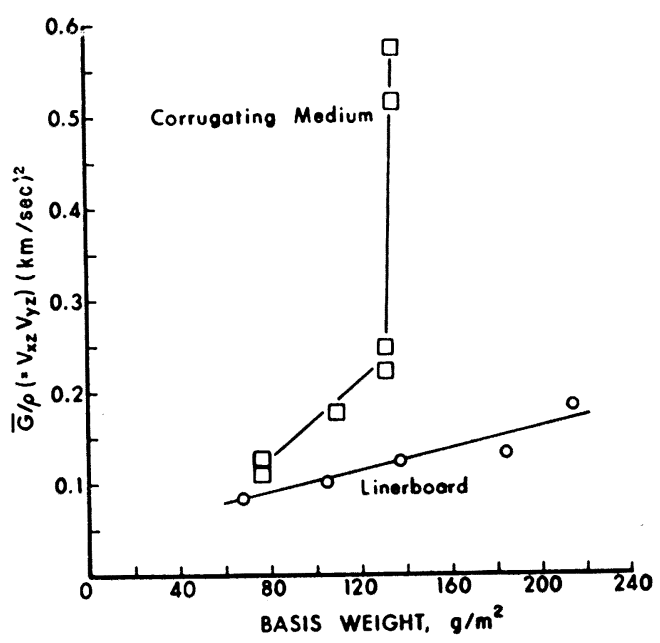

Fig. 16 Ultrasonic out-of-plan mean shear modulus vs. basis weight remaining after grinding.

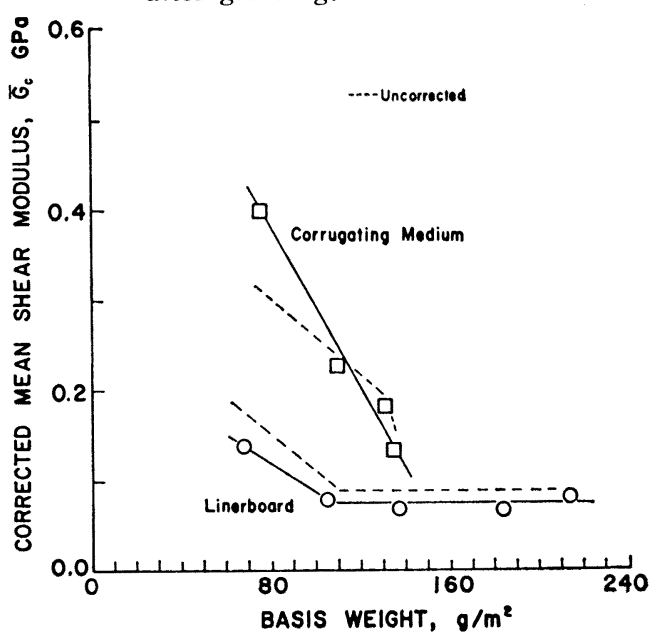

Fig. 17 Variation of out-of-plane corrected mean shear modulus determined mechanically with basis weight for ground disk samples.

紙を緊張乾燥させると，引張った方向の曲げ剛さが 増し, 逆に他の 2 方向の岡さは減少すると同時に厚み が増加することも知られている。G.A. Baum らはこ 
圧縮にともなって生じる面外弾性率 $G_{x z}, G_{y z}$ もまた 重要な因子であることを実証した。

Heated platen

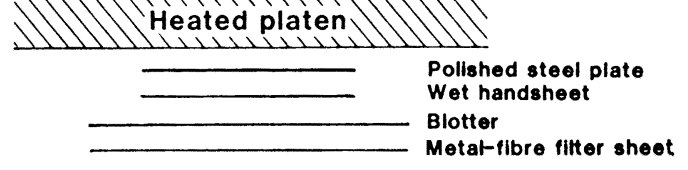

1/l//hilineated platen

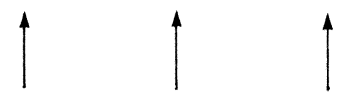

Fig. 18 The arrangement for press-drying hand-sheets.

の現象を视贩するための理論的モデルとして，単純な 幾何学的モデルを使って綮張乾燥時のひずみし厚さの 関係を表わす式を管いた。

力学特吽のうち不縮特州:，特に $x$ または $y$ 方向の压 縮は丰験方法が容易でないために来知の分野である。 最近になってさまざまな装㙋が考案されて，面内の圧 䍃测定も比較的容易にできるものが工夫されてきた。 R.E. Mark らは円筒を圧維する方法を使い，圧縮強 さは暻さ, 密度に関係しているのはもちろんであるが,

\section{4. プレスドライング}

プレスドライングは近年，紙の特性を改質する一つ の方法として注目されている。プレスドライングでは 紙を 2 枚の金網にはさんでプレスするために，通常の ウェットプレスのような金属板をフェルトによってプ レスされたものと比較するには無理がある。PPRIC のD.H. Pageらのグループではこの操作を改良し， ウェットプレスと同様な条件下でプレスドライングす る方法を考案した。この方法では図 18 に示すように， 湿紙を金属板とブロッター（吸取紙）と金属維維のフ イルターとの間にはさみプレスドライングするもので ある。この方法で得られた紙と同じ条件でウェットプ レスして得られた紙の密度と光散乱係数の関係を図19 に示す。高収率 UKP の場合は全く羊がないが，その 他のパルプでは傾问は似ているが，同じ曲線にはなら ない。プレスドライングでもウェットプレスでも同様 な紙層が作られるであるらが細部は異なるであろう。 特に TMP では大きな差がある。ウェットプレスした TMP では繊維のつぶれは少ないが，プレスドライン

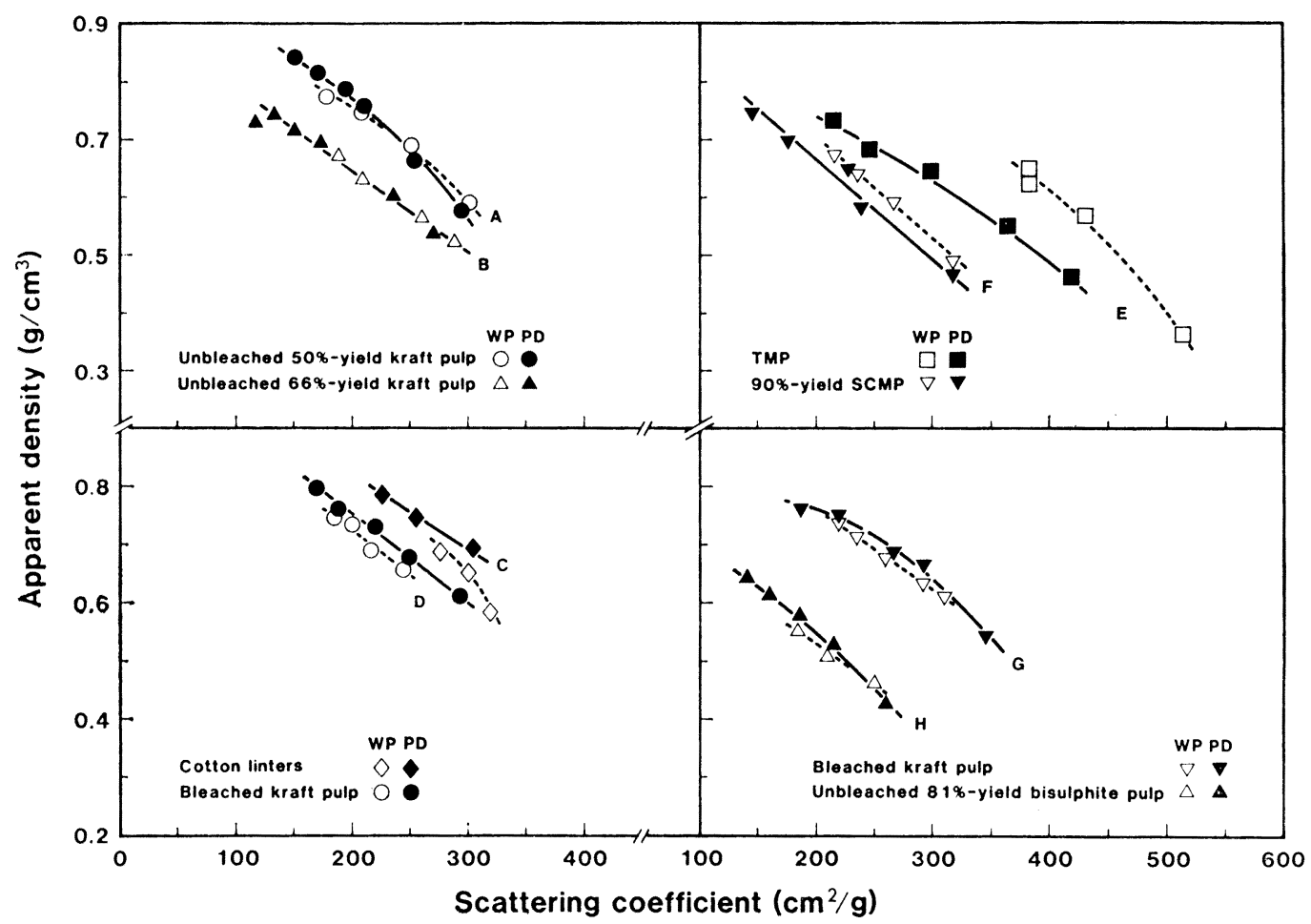

Fig. 19 Plots of apparent density against scattering coefficient for sheets of various pulps wet-pressed and press-dried over a range of pressures. 
川

章 夫

Table 9 Effect of drying temperature on oak furnish $\left(205 \mathrm{~g} / \mathrm{m}^{2} \text { basis weight }\right)^{* 1}$

\begin{tabular}{|c|c|c|c|c|c|c|}
\hline \multirow{2}{*}{$\begin{array}{l}\text { Pressing force and restraint: } \\
\text { Web temperature while drying : }\end{array}$} & \multicolumn{3}{|c|}{ Intermittent restraint } & \multicolumn{3}{|c|}{ Continuous restraint } \\
\hline & $71^{\circ} \mathrm{C}$ & $100^{\circ} \mathrm{C}$ & $144^{\circ} \mathrm{C}$ & $71^{\circ} \mathrm{C}$ & $100^{\circ} \mathrm{C}$ & $144^{\circ} \mathrm{C}$ \\
\hline \multicolumn{7}{|l|}{ Property } \\
\hline Density $\left(\mathrm{kg} / \mathrm{m}^{3}\right)$ & 800 & 800 & 800 & 975 & 975 & 975 \\
\hline Burst (kPa) & 503 & 548 & ${ }^{* 2} \mathbf{6 0 3}(+20)$ & 614 & 765 & $*^{2} 848(+37)$ \\
\hline Tensile strength $(\mathrm{kN} / \mathrm{m})$ & 6.92 & 7.62 & $8.41(+22)$ & 9.1 & 10.2 & $11.3(+24)$ \\
\hline Tensile strain (at failure $(\%)$ & 2.65 & 2.55 & 2.60 (NC) & 2.5 & 2.82 & $2.38(-5)$ \\
\hline Extensional stiffness $(\mathrm{kN} / \mathrm{m})$ & 946 & 1,006 & $955(\mathrm{NC})$ & 1,235 & 1,182 & $1,296(\mathrm{NC})$ \\
\hline Compressive strength $(\mathrm{kN} / \mathrm{m})$ & 3.94 & 4.24 & $4.50(+14)$ & 4.97 & 5.32 & $5.67(+14)$ \\
\hline Compressive strain (at failure $(\%)$ & 0.77 & 0.73 & $0.70(-9)$ & 0.72 & 0.73 & $0.64(-11)$ \\
\hline Bending stiffness $(\mathrm{mN}-\mathrm{m})$ & 2.65 & 2.75 & $3.04(+15)$ & 2.25 & 2.25 & $2.16(\mathrm{NC})$ \\
\hline Fold number (double folds) & 37 & 63 & $39 \quad(*)$ & 81 & 154 & $57 \quad(*)$ \\
\hline Tear strength $(\mathrm{mN})$ & 1,638 & 1,373 & $1,687(\mathrm{NC})$ & 1,569 & 1,520 & $1,618(\mathrm{NC})$ \\
\hline Water drop absorption (sec) & 170 & 80 & 140 (NC) & 130 & 400 & $640(+392)$ \\
\hline Wet tensile strength $(\mathrm{kN} / \mathrm{m})$ & 0.24 & 0.42 & $0.81(+237)$ & 0.21 & 0.46 & $1.17(+388)$ \\
\hline MD tensile strength $(\mathrm{kN} / \mathrm{m})$ & 9.5 & 12.3 & $13.0(+37)$ & 12.9 & 15.5 & $17.0(+32)$ \\
\hline MD extensional stiffness $(\mathrm{kN} / \mathrm{m})$ & 1,223 & 1,454 & $1,537(+25)$ & 1,515 & 1,760 & $1,839(+21)$ \\
\hline
\end{tabular}

* Maximum (at $190^{\circ} \mathrm{C}$. Declines at higher and lower temperatures.

*1 Results refer to cross machine direction (CD) unless otherwise specified.

$* 2$ Numbers in parentheses reflect change from $71^{\circ} \mathrm{C}$ to $144^{\circ} \mathrm{C}$--expressed as a percentage of the $71^{\circ} \mathrm{C}$ value. (NC) refers to change of less than $5 \%$.

グでは㵶維がつぶされるために密度が高くなるが，逆 に光散乱係数は減少する。ウェットプレスされた紙と プレスドライングされた紙では平衡水分显が異なり, これが密变と光散乱係数の低下をもたらすことにもな る。更に表面粗さのわずかな差が, 密度测定に影響を 与えることも考えられる。

D. E. Gunderson は圧力上温度をそれぞれ独立に コントロールできるプレスドライング装置を若案した。 その概略を図 20 に示す。网からわかるよらにプレス 用のプレートからの熱㥀接湿紙にかかるのではなく， シリンダー冈の水蒸気を通して加熱されるために熱と 圧力が独立に変えられることができる。また，圧力は 連続的に加圧できるのみならず, $50 \mathrm{msec}$ あるいは 100 msec のパルス圧維もできるよらに工夫されている。 オーク材のパルプをプレスドライングして得られた板 紙の物性試験結果を表 9 に示す。同一密度で此較する と破裂, 引涱強さは約 $20 \%$ 増加するが破断伸び, 引裂 きはほとんど変化がない。最も效朵が顕著に現われる のは湿紙引張強さで, $71^{\circ} \mathrm{C}$ から $144^{\circ} \mathrm{C}$ に上げた場合, 2 倍強の強さが得られた。

連続プレスはパルスプレスに比べて，ほとんどの特 性が改良される。特汇密度の増加は著るしく, 引張り, 曲げ剛さ，破裂，圧綩強さなどが 15２0\% 増加する。

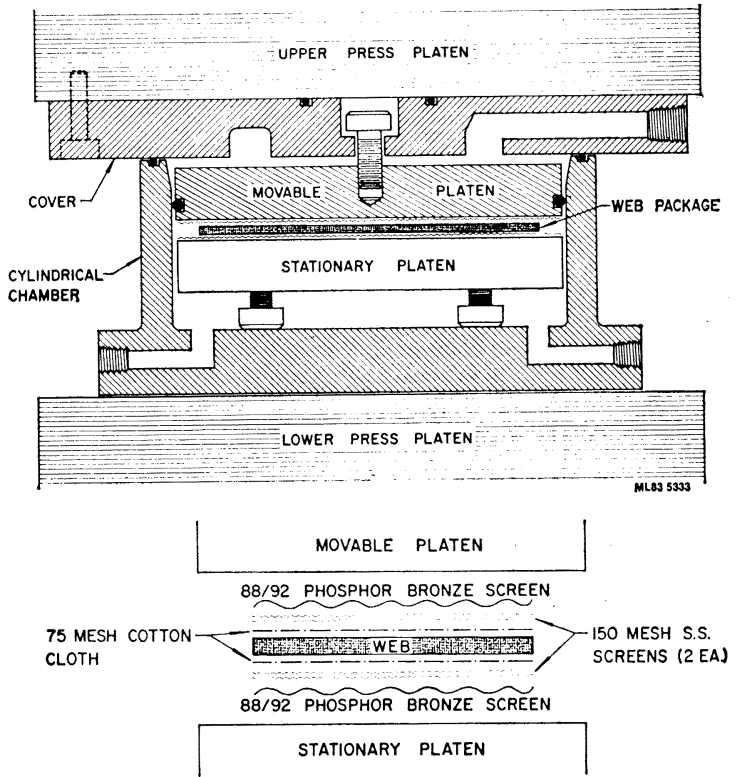

Fig. 20 Pressurized platen press.

プレスドライングではへミセルロース, リグニンが流 動化され，繊維の采軟怔が増加するために瀻維閆結合 が強固になる。また, リグニンが生成された紼維間結 合をカバーするために湿潤強度が增大寸ると考えられ 


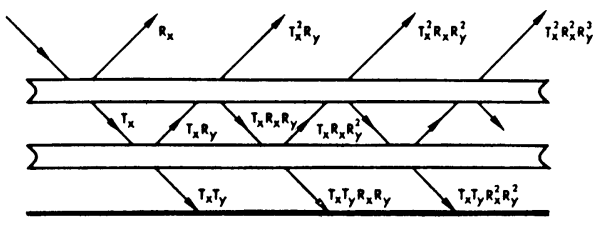

Fig. 21 Interaction of an incident light beam with two layers placed upon a black background.

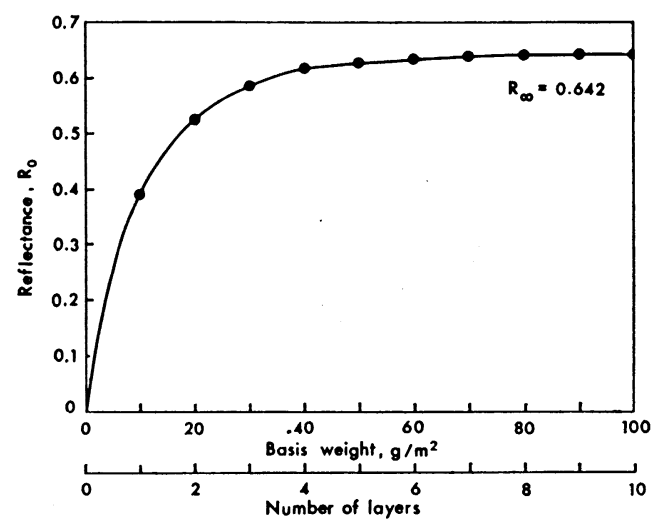

Fig. 22 Numerical example of reflectance as a function of basis weight. The points are calculated from Stokes theory for the addition of layers each of basis weight $10 \mathrm{~g} / \mathrm{m}^{2}$, reflectance 0.388 and transmittance 0.545 . The continuous curve is calculated from Kubelka-Munk theory for the coefficients $\mathrm{s}=\mathrm{cm}^{2} / \mathrm{g}, \mathrm{k}=\mathrm{cm}^{2} / \mathrm{g}$. Superimposition is perfect.

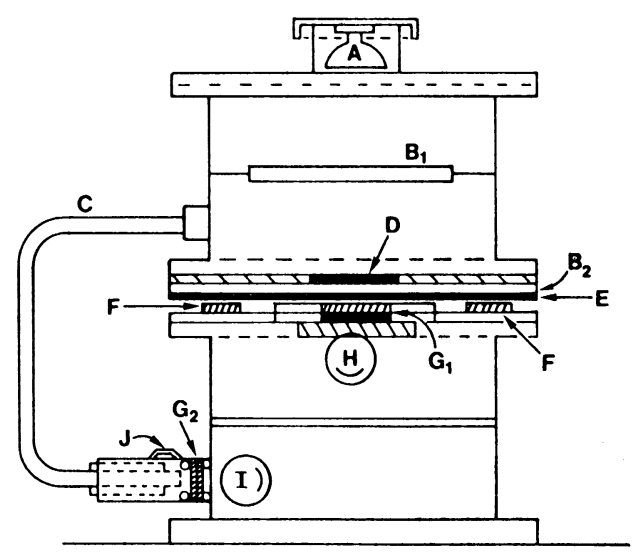

Fig. 23 Schematic of optical transmittance instrument.
る。

\section{5. 光学特性}

紙の光反射率を計算する方法としては良く知られた Kubelka-Munk の理論がある。実用性の面から考え ると, Kubelka-Munk の理論は複雑であるため, よ り単純な概念を用いて同じ結果が得られれば, 光散乱, 光透過の現象をよりよく理解できるであろう。A. $M$. Scallan は紙が多層構造になっているものと仮定し, 各層は Stokes の光反射理論が適用できるとして, Kubelka-Munk の理諭と同じ結果を䍹くことができ ることを証明した。図 21 に示すような層状の物質に よる反射, 透過を考えると, $\mathrm{n}$ 層からなる絟の光反射 率 (Tn) はそれぞれ次式で与えられる。

$$
\begin{aligned}
& R_{n}=R_{1}+\frac{T_{1}{ }^{2}-R_{n-1}}{1-R_{1} R_{n-1}} \\
& T=\frac{T_{1} T_{n-1}}{1-R_{1} R_{n-1}}
\end{aligned}
$$

この式は基本的に Kubelka-Munk の式と同一であり， 異なる点は Stokes の理論から導いた式は和の形で与 えられるに対して, Kubelka-Munk の式は積分の形 で与えられているといらことである。Kubelka-Munk の式と上記の式を使って計算した紙の反射率は図 22 に示すように完全に一致する。

紙の繊維間結合を知る一つの指標として光散乱係 数が良く使われる。光散乱係数を計算するためには Kubelka-Munk の理論従って $R_{0} と R_{\infty}$ を測定しな ければならないが，坪量の高い板紙では $R_{0}$ と $R_{\infty} の$ 差が小さく, この計算上の誤差が生じやすい。それに 代る方法として $R_{0}$ と $T$ が測定できれば光散乱倸数を 計算することができる。J.M. Knox とD. Wahren は図 23 のような透過光を测定する装置を試作し，そ の测定値から坪量 $400 \sim 1,000 \mathrm{~g} / \mathrm{m}^{2}$ の板紙の光散乱係 数を計算した。この装置は坪量の高い板紙などの相対 結合面積を知る上に有效な道具となることであろう。

\section{6. 湿潤と力学特性}

紙は水を吸収すると脸張する。自由乾燥した紙と緊 張乾燥した紙ではその力学的特性汇大きな差がある。 Xerox のC. Green はこのことに注目し紙の湿潤膨 張率 (RH 10\%当りの長さの変化\%) は紙の引㖘強さ と密接な関係があることを実証した。湿潤膨張率はあ る一定の荷重での自然対数と直線関係にある(図 24)。 この直線関係はパルプの特性であり, 乾燥方法とは独 立である。

紙を湿潤させたり, 乾燥させたりする過渡的な過程 


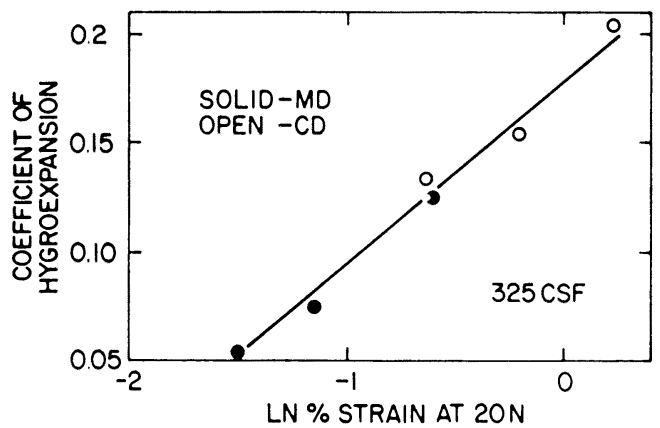

Fig. 24 Hygroexpansivity versus In strain.

においては，平衡状態における特性とことなり，湿潤 または乾燥速度によりさまざまな特性が生まれる。そ の影響が最も顕著に現われるのはエネルギー吸収量で ある。E. Back らが测定した例を図 25 に示す。過渡 期におけるエネルギ一吸収量は湿潤・乾燥の場合とも に平衡值よりも高い。すなわち，このような過渡期で は瞬間的に紙の力学的強度が上ることを意昧している。 にもかかわらず，曲げ剛さは一時的に減少する。この 理由として，水分の移動にともならセルロース分子の 易動性と紙層内に応力こう配が生ずるためと考えるこ とができるが確証は得られていない。

湿潤・乾燥を繰返し行った板紙，特に段ボール紙の 圧縮クリープ特性は製品品質に関わる重要な課題であ る。V.L. Byrd は段ボールのクリープ速度に与える 繰返し湿潤・乾燥の影響について検討した。繰返し湿 潤のクリープ速度は, 平衡状態の場合より $2 \sim 9$ 倍速 くなり，高収率パルプの方が低収率パルプより速い。 ライナーと中しん原紙を別々に試験し，それぞれのク リープ夷験と段ボール製品のクリープを比較した。結 果は表 10 に示す。実際の段ボールのクリープ速度は ライナーと中しん原紙のそれぞれの值よりも，4〜5倍 速い。これはクリープ現象が単に個々の構成要素だけ によるものでなく別の原因があると思われる。その 1 つは試験方法そのものの問題点上段ボール製造に用い る水溶性接着剤にもよるのではないかと考えられる。

水分の影響は紙武験の場合にも問題となる。その例 として R.H. Crotogino は新聞用紙をカレンダー掛 けした後の厚さおよび表面粗さについて武験条件の影 響について検討した。厚さおよび表面粗さに最も影響 を及ぼすのはカレンダーロールの線圧と通紙速度で， 線圧が上ると厚さ，表面粗さはともに減少する。その 反対に通紙速度が速くなると厚さ，行面粗さは増大す る。カレンダー時の水分が増大すると厚さ, 表面粗さ はともに娍少する。これは紙試騃を $\mathrm{RH} 50 \%, 23^{\circ} \mathrm{C}$ で 3 日調整した後に行った場合であるが，調整湿度を
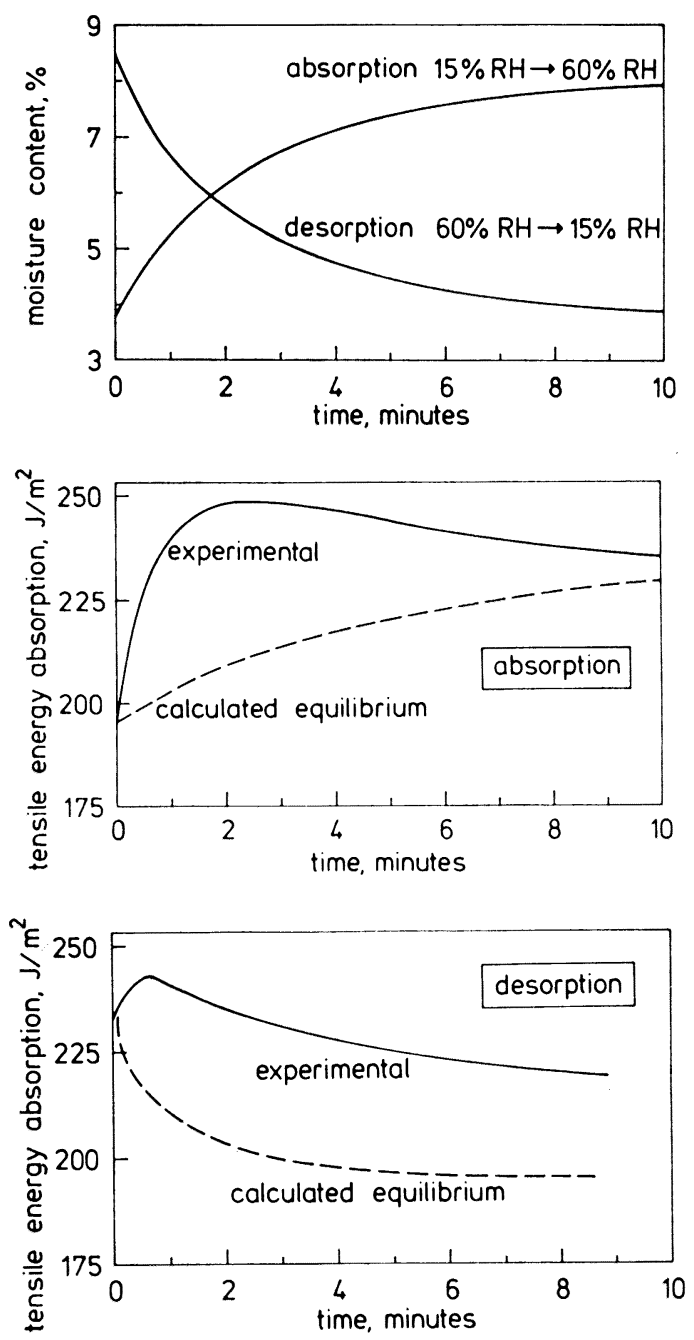

Fig. 25 Moisture content and tensile energy absorption in a $115 \mathrm{~g} / \mathrm{m}^{2}$ kraft sack paper during absorption and desorption, $15 \%$ R. H. $\rightarrow 60 \%$ R. H. respectively $60 \%$ R. H. $\rightarrow 15 \%$ R. H., versus time from the change in ambient humidity.

変えて試験をすると, 水分最の増加とともに原さ, 表 面粗さが増大寸る。従って，水分増加の效果は互に打 ち消すような働きをすると思われる。図 26 は線圧 88 $\mathrm{kN} / \mathrm{m}$, 速度 $152 \mathrm{~m} / \mathrm{min}$ で水分!最変えてカレンダー 掛けした紙の厚さと表面粗さを示したものであるが， カレンダー直後あるいはカレンダー侍の水分を保持す るように調整した場合は, カレンダーの效果はほとん どみられない。しかし, カレンダー後, 標準状態 $(\mathrm{RH}$ $50 \%, 23^{\circ} \mathrm{C}$ ) で調整するとカレンダ一時の水分量の増 
Table 10 Comparison of experimental short column and component creep rates and lignin contents.

\begin{tabular}{|c|c|c|c|c|c|c|c|}
\hline Item & 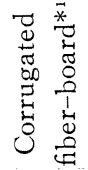 & $\begin{array}{l}\text { Calculated }{ }^{* 2} \\
\text { combined } \\
\text { board lignin } \\
\text { content } \\
(\%)\end{array}$ & $\begin{array}{l}\text { Combined } \\
\text { board cyclic } \\
\text { RH creep } \\
\text { rates }{ }^{* 3} \\
\left(10^{-4} \% / \mathrm{hr}\right)\end{array}$ & $\begin{array}{l}\text { Component } \\
\text { specimens }\end{array}$ & $\begin{array}{l}\text { Components } \\
\text { cyclic RH } \\
\text { creep rates } \\
\left(10^{-4} \% / \mathrm{hr}\right)\end{array}$ & $\begin{array}{l}\text { Average of } \\
\text { components } \\
\text { cyclic } \mathrm{RH} \\
\text { creep rates } \\
\left(10^{-4} \% / \mathrm{hr}\right)\end{array}$ & $\begin{array}{c}\text { Ratio } \\
\text { combined } \\
\text { board } \\
\text { components } \\
\text { average }\end{array}$ \\
\hline Virgin & 580 & 11.18 & 84.5 & $\begin{array}{l}\mathbf{6}, 931 \mathrm{~L}^{* 4} \\
\mathbf{6}, 929 \mathrm{C} * 5\end{array}$ & $\begin{array}{l}14.4 \\
31.5\end{array}$ & 23.0 & 3.67 \\
\hline Recycled & 595 & 10.68 & 108.5 & $\begin{array}{l}6,986 \mathrm{~L} \\
6,985 \mathrm{C}\end{array}$ & $\begin{array}{l}26.3 \\
17.1\end{array}$ & 21.7 & 5.00 \\
\hline $\begin{array}{l}\text { Virgin with } \\
\text { bark }\end{array}$ & 596 & 10.23 & $77.1^{* 6}$ & $\begin{array}{r}6,990 \mathrm{~L} \\
\mathrm{p} 1,064 \mathrm{C}\end{array}$ & $\begin{array}{l}30.0 \\
40.0\end{array}$ & 35.0 & 2.20 \\
\hline $\begin{array}{l}\text { High yield with } \\
\text { bark }\end{array}$ & 598 & 17.79 & 218.0 & $\begin{array}{r}\mathbf{6 , 9 8 9} \mathrm{L} \\
\mathrm{p} 1,064 \mathrm{C}\end{array}$ & $\begin{array}{l}41.3 \\
40.0\end{array}$ & 40.7 & 5.36 \\
\hline $\begin{array}{l}\text { High yield } \\
\text { without bark }\end{array}$ & 599 & 17.43 & 170.8 & $\begin{array}{r}6,988 \mathrm{~L} \\
\mathrm{p} 1,064 \mathrm{C}\end{array}$ & $\begin{array}{l}32.3 \\
40.0\end{array}$ & 36.2 & 4.72 \\
\hline
\end{tabular}

$* 1$ See experimental section for description.

$* 2$ Weighted averages based on component's basis weights and take-up factor for A-flute (1.55).

*3 Data of Byrd and Koning, Tappi 61(6) : 35 (1978).

$* 4 \mathrm{~L}=$ linerboard.

$* 5 \mathrm{C}=$ corrugating medium.

*6 This creep rate should be compared with corrugated fiberboard 597 (made from the same furnish but without bark) whose average creep rate is $62.5 \times 10^{-4} \% / \mathrm{hr}$.
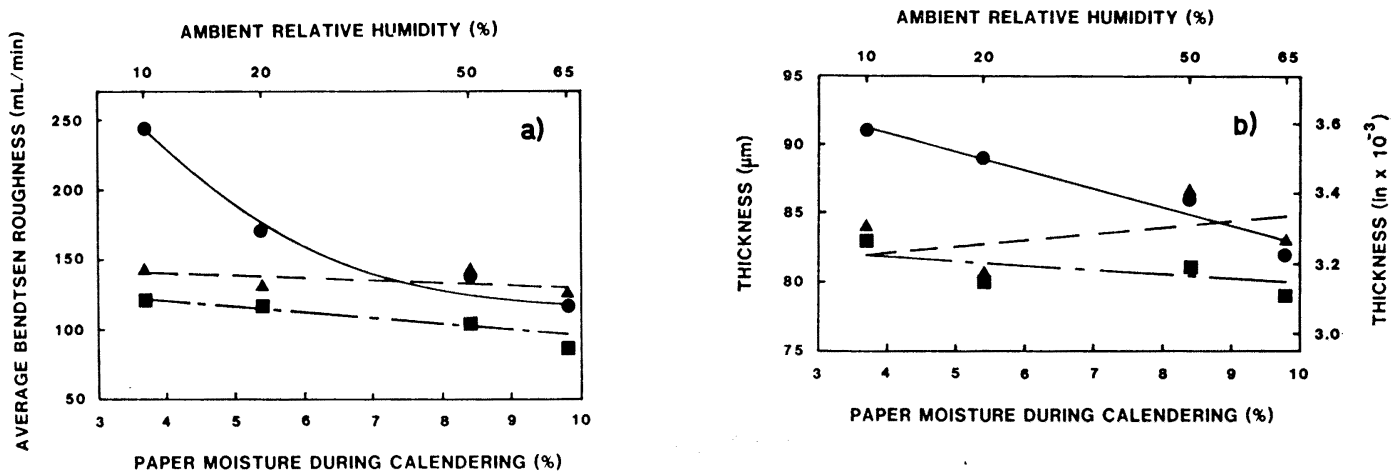

Testing conditions :

$-\mathrm{D}=3, \mathrm{M}_{\mathrm{T}}=8.4 \%$ (three-day testing at $23^{\circ} \mathrm{C}$ and $50 \% \mathrm{RH}$ )

$\cdots \cdots \Delta \cdots \cdot \mathrm{D}=3, \mathrm{M}_{\mathrm{T}}=\mathrm{M}_{\mathrm{C}}$ (three-day testing in calendering atmosphere)

- $\square$ - $-\mathrm{D}=0, \mathrm{M}_{\mathrm{T}}=\mathrm{M}_{\mathrm{C}}$ (immediate testing)

Calendering conditions : Nip load

$\mathrm{L}=88 \mathrm{kN} / \mathrm{m}$

Calender speed

$\mathrm{S}=152 \mathrm{~m} / \mathrm{min}$

Roll temperature

$\mathrm{T}=93^{\circ} \mathrm{C}$

Fig. 26 Variation of (a) Bendtsen roughness and (b) thickness with moisture content during calendering.

加にともなって厚さ，表面粗さが娍少する。この結果 から言えることはカレンダーの效果を適確に判断する ためには試験条件を充分に注意して選ぶ必要があると いらことと，カレンダー排けした紙を弇庫に保管する 際にはその湿度条件によってはカレンダ一效果が消え てしまう闭能性があるといらことである。

\section{7. まとめ}

以上紙の物性，特にその力学的特性を中心に 1983 International Paper Physics Conference で発表され た論文の概要を紹介した。この報告では紹介すること ができなかったが，ティシュの窞能評仾や，インクジ 


岡川 章 夫

Hット印刷に要求される䋊特性の基礎的研究なども発 表された。また, 第 1 日目と第 3 日目の午後には吒解 と織維間結合に関するパネル討論会がそれぞれ開催さ れ活発な討議が行われた。

吒解のパネルはフィンランドの K. Ebeling, IPC のD. Wahren およびA. Nissan の 3 名で, STFI の E. Back が司会した。現在吒解とは何かについて の統一された概念はない。吒解によって何を澾成する のかは紙品質として何を要求されるのかによって異な ってくる。叮解により, 纎維が柔軟になり, 䋐維間の 接触面積が増大し, その結果として強度が上ると言わ れているが，プレスを強化しただけでも相対結合面積 を増加させることはできるが，強度はそれほど上らな い。吒解が強度を引き出してくれるが, そのメカニズ ムはよくわかっていない。フィブリル化のみによる強 度増加には限界があり, 叨解で生成するファインも強 度増加化重要な役割をはたしている。紙の強度は䋐維 の強度と瀻維間結合強度の雨者が関与しているので, 吒解により繊維強度を減少させるようなことはすべき でないが，この点についてはあまり注意がはらわれて いない。工場現場ではそれぞれ品質の異なるパルプか ら同じ品質の紙を作ることが日常行われており，現場 の作業員はどうすれば特定の品質が得られるか知って いるにもかかわらず，研究を担当している人達は叨解 で何が起り，品質がどう変るかは全くわかっていない
と言っても良いと，Nissan は研究鱼に対して警仯を 与えている。また，今までの吒解に関する矿究ではフ リーネスをいかに测定するか, フリーネスとは们を意 味するかとの議論が多く, 本来の夘解で何が起るのか といら蝑閵はいまだに解決されていない。ようやく最 近になって外部フィブリル化, 刚制フィブリル化, フ アインの生成には何が必要であり，そ狆が組品質にど ら影響するのかがわかりかけてきた所である。

一方, 結合㳊関寸るパネル討䑳会では D. Page, C. Feller, R. Mark がパネルで, 们会はV V.L. Byrd が務めた。瀻維間結合といってもそれぞれの人によっ て解积が異なる。䋐維開の接触泊积の指標としては光 学的接触面程, ガス吸等しない而稤, 密度などがあり, 結合強度にしても， $x, y, z \jmath j$ 问の強度が結合強度を 直接表わしているものでもない。また，結合のしかた にしても水素結合, Van der Waals 力, 立休的から み合い, 結合而の浰解あるいは共有結合であるのかも はっきりとしていない。接触而稳がすべて絬合而䅡で あるといらわけでもない。禹度や比敬乱係数が絬合の 指標としてよく使わ机るが，こ礼も特定のパルプにつ いては比較できても，パルプが異なるものを比較して も強度を予测することは因難である。紙そのものの特 性を理解するためには吒解の作䏘や結合について更に 今後の研究がなされなければならないこ上をこの 2 つ のパネル討諭会は物湿っている。 